\title{
Accounting Capstone Course Design: Using The Internet To Modernize A Graduate Accounting Capstone Course
}

Diane S. Bloom, Kean University, USA

Clemense Ehoff Jr., Kean University, USA

\begin{abstract}
This second paper describes how the Internet was used to modernize a graduate accounting capstone course to enhance student interest and learning, and is an extension of an earlier paper that examined a similar approach with an undergraduate accounting capstone course. Course content was developed from contemporary issues and cases obtained from the Internet. Benefits, drawbacks, and feedback from students who completed the updated course are presented as a basis for future study. The concepts and techniques presented in this analysis can easily be applied to capstone courses in other disciplines.
\end{abstract}

Keywords: Capstones Courses; Accounting; Internet; Curriculum Development

\section{INTRODUCTION} n 2009, a paper describing how the Internet could be used to bring contemporary issues into an undergraduate accounting capstone course to enhance student interest and learning was presented at the 2009 Clute Institute LBER \& TLC Las Vegas Conference (Ehoff, 2009). The paper noted that many existing case studies often used in these courses might not be at the forefront of items currently under examination and/or debate by the accounting profession. Based on course development and delivery experience at a major Eastern University, the benefits and drawbacks of using the Internet to select contemporary accounting issues was presented and compared to existing research findings as a basis for future study, and as a model for undergraduate capstone courses in other disciplines.

The present paper describes how the Internet was used to modernize a graduate level accounting capstone course to enhance student engagement and learning. Course content was developed from contemporary issues and case studies, all obtained from the Internet. Benefits, drawbacks, and feedback from students who completed this updated course are presented as a basis for future study. The concepts and techniques presented in this analysis can easily be applied to graduate level capstone courses in other disciplines.

The graduate level course used for this project was a seminar in professional accounting practice that dealt with competencies expected of a contemporary accounting professional. A case-study structure had been used in the past, and would be used in this project. The text used previously in this course had gone out of print and a replacement had not been chosen. The remainder of this paper describes the results of our graduate level accounting capstone course modernization experiment by using the Internet.

\section{COURSE STRUCTURE}

The basic structure of the course consisted of fourteen classes. Eleven of the classes were used for seminars that focused equally on contemporary issues and case studies. Two classes were reserved for student presentations of group projects. One class was reserved for a final exam, which gave the students an opportunity to summarize what they had learned from the seminars. 
Five themes, which had already been developed in the undergraduate accounting capstone course experiment, were used here as a foundation for the contemporary issues portion of the seminars: 1) The Role of Contemporary Accounting, 2) Professional Research, 3) Emerging Issues, 4) Professional Auditing, and 5) Consulting and Other Services. We would spend from two to three weeks on each theme. Obtaining contemporary issues was simply a matter of entering a theme into an Internet browser and searching accounting websites, such as the American Institute of CPAs (www.aicpa.org), the Financial Accounting Standards Board (www.fasb.org), the International Accounting Standards Board (www.iasbweb.org), and the major accounting firms. We purposefully kept search instructions broad to allow for freedom of exploration. Students and instructor would share and discuss the findings of their Internet search.

The Trueblood Case Studies (Deloitte Foundation, 2010) were chosen for the accounting and auditing aspects of the course. These cases are based upon complex accounting and auditing issues found in actual practice, and require students to research financial accounting and auditing standards to solve the case issues. We consider these cases suitable for a graduate level accounting course. Nine case studies were chosen for the course. An income tax case dealing with Roth IRA conversions and a simple business valuation case were developed by the instructor and used to round out the case studies. Students were required to submit a written analysis for five of the eleven case studies.

Accounting \& Auditing Research: Tools and Strategies (Weirich, Pearson, \& Churyk, 2010), a research primer tailored for accounting and tax issues, was selected as a text for the course. It proved to be a handy resource for navigating through various professional databases.

\section{THEME ACTIVITIES}

Students and instructor performed searches and brought their research to the classroom to include in the discussion. Presented below is a brief summary of our discussion for each of the five themes.

\section{The Role of Contemporary Accounting}

After examining the results of the Internet search, the class identified several factors that have dramatically changed contemporary accounting. First, there has been an "explosion" of new accounting standards put forth over the last ten years, and there appears to be no end in sight. Second, advances in technology have changed nearly every aspect of accounting, from data collection and storage to auditing working papers. Contemporary accountants must go far beyond basic computer literacy to keep pace with rapidly changing technology. Third, the recent rash of audit failures, large company collapses, and the demise of Arthur Andersen have dealt a severe blow to the reputation of the CPA profession, and caused a flood of new regulations. Fourth, the increased complexity of contemporary business has correspondingly expanded the breadth of knowledge required of the contemporary accountant. As a result, there has been a significant increase in specialized credentialing.

\section{Professional Standards and Emerging Issues}

Since 2002, the Financial Accounting Standards Board (FASB) and the International Accounting Standards Board (IASB) have been feverishly attempting to bring Generally Accepted Accounting Principles (GAAP) and International Financial Reporting Standards (IFRS) closer together (known as convergence). By the end of 2011, the Securities and Exchange Commission (SEC) is hoping to decide whether to 1) continue on its present revision path, 2) adopt IFRS altogether, or reject IFRS. We asked students to examine two of these accounting standards proposals: 1) a revised standard for financial statement reporting, and 2) a revised standard for leases. The purpose for choosing these was to give the students the opportunity to observe how financial standards are developed. Typically, a discussion letter is issued describing the proposal and requesting comments from interested parties. Comment letters are reviewed and then used as input for developing an exposure draft. The exposure draft is issued and comments are again requested. These comments are reviewed and incorporated into the final accounting standard. All discussion letters, comment letters, exposure drafts, additional comment letters, written proceedings and sometimes videos of board meetings are available on the FASB's website. 
The October 2008 discussion letter proposing revisions to financial statement presentation was a 165-page document suggesting radical changes to financial statements as they are currently presented (FASB). Under this proposal, the balance sheet and income statement would be structured similar to the cash flow statement, classifying accounts as operating activities, investing activities, and financing activities. Presentation of cash flow statements using the indirect method would no longer be allowed. A management approach was suggested for disaggregation of account balances (now required to comply with the new format). This proposal stirred much controversy. More than two hundred comment letters, ranging in length from 1-50 pages, were received from practitioners, associations, accounting firms, and others in the business community. Others used the Internet directly to fill the web with commentary; some favorable and most unfavorable. On July 1, 2010 the Boards posted a draft of the exposure draft on the FASB website. Shortly after the posting, the financial statement presentation project was postponed, pending resolution to other outstanding (and in the eyes of the Boards more critical) proposals. The status of this project has not changed.

On July 17, 2009, the Boards issued a discussion letter proposing a new financial standard for leases. Under the new proposal, operating leases, which had been expensed, would be capitalized similar to capital leases, creating a right-to-use asset and a corresponding liability for the lease obligation. After reviewing comment letters, the Boards issued an exposure draft on August 10, 2010. This project, like the one mentioned above, is filled with controversy and has not been completely finalized.

The students found this component of the FASB website rather sobering; in the past students used the website to obtain existing accounting standards. Their perusal of the discussion letters, comment letters, and exposure drafts gave them a comprehensive introduction to the standards setting process. The classroom discussions that followed resembled an extension to the comment letters. Indeed, this was the highlight of the course.

We then turned our attention to the SEC's upcoming decision about whether or not to adopt International Financial Reporting Standards. Students entered the class with a somewhat superficial grasp of the push toward IFRS. We asked the students to consider the following questions in their Internet search:

1. Should there be one set of common financial reporting standards?

2. Are GAAP superior to IFRS?

3. Is adoption of IRFS in the best interest of U.S. investors?

The students agreed that there should eventually be one set of international financial standards for public companies. They did not agree that GAAP should be discarded in favor of IFRS. Finally, they wondered how the SEC's relinquishing of oversight control over financial reporting standards was in the best interest of U.S. investors. Indeed, that question remains unanswered.

\section{Professional Auditing}

We began our discussion of professional auditing by highlighting an array of audit failures. The audit failures of WorldCom, Enron, Adelphia, HealthSouth, Xerox, Tyco International Ltd., and others have dealt a serious blow to the reputation of national and international auditing firms. Next, we discussed a 2002 article, which noted that audit firms gave unqualified opinions to $42 \%$ of the public companies that subsequently filed for bankruptcy within a year (Weiss). We asked the class to consider that auditing, as we know it, is broken and can no longer be relied upon.

The students agreed that the rash of recent audit failures had severely damaged the reputation of the accounting profession and that the audit experience was clearly not living up to users' expectations. They explored the notion that user expectations were unrealistic, noting that the purpose of an audit was to provide reasonable assurance against material misstatements, not a guarantee. Lastly, the students noted that little has been done to change users' expectations. 


\section{Consulting and Other Services}

In this theme, students were asked to consider the future of the accounting profession. Two topics dominated the discussion: 1) specialization credentials, and 2) outsourcing.

The students noted that business complexity, technology, and increased regulation have placed severe demands on the contemporary accountant. As a result, future growth appears to be focused upon obtaining specialization credentials. Most students felt that most consumers would prefer a CPA who is also a Certified Financial Planner (CFP) to a CPA who merely specializes in financial planning

Many students were surprised to learn that U.S. accounting firms will outsource the preparation of more than a million tax returns in 2011. Outsourcing has far reaching implications on how accountants will structure their tax services in the future. Clearly, accounting firms will be able to handle more clients in the future, lower tax return processing costs, and redirect staff time to more complicated tax issues.

\section{CASE STUDIES}

The nine Trueblood case studies chosen for this course covered complex accounting and auditing issues found in actual practice, and required students to research financial accounting and auditing standards to solve the case issues. The students found these cases quite challenging. Classroom discussions were robust and sometimes intense.

Two cases were developed by the instructor: 1) A Roth IRA conversion case, and 2) a simple business valuation case. As with the Trueblood case studies, these were based upon actual practice situations. The students enjoyed the practical relevance of these case studies.

\section{GROUP PRESENTATIONS}

Two classes were reserved for six group presentations. The topics included international financial reporting standards, deferred tax savings options, and current and future accounting pronouncements. Each presentation included a PowerPoint slide show and participation by each member of the group.

The group presentations fared far better than anticipated. The presentations were interest, current, and well researched, thanks mostly to their Internet research efforts. Many interesting questions and observations resulted from these presentations.

\section{FINAL EXAM}

The course concluded with a written final exam. Students were asked to respond to a series of questions broadly based upon the seminars. It was extremely satisfying to learn that every student had acquired a firm grip on the major contemporary issues facing the accounting profession.

\section{STUDENT SURVEY}

At the conclusion of the course, we asked students to comment on the worthiness of the course design and suggest improvements. The students unanimously agreed that the design of this course was ideal and a welcome departure from other courses in their curriculum. They remarked that the case studies were challenging and gave them practice in applying accounting standards to actual practice type problems.

The only change that the students suggested was to select a different text. As it turned out, their skills at navigating around the Internet rendered the research primer unnecessary. A GAAP guide that provides more readable interpretations of accounting standards along with application guidance from a highly trained professional staff will be used in the future. 


\section{REFLECTIONS}

Using the Internet to incorporate contemporary issues in this graduate accounting capstone course gave loft to the capstone course and energized student engagement resulting in increased time on task beyond the classroom, and success in applying higher-order thinking skills related to the "real time" application of GAAP. This study found the instructor's comfort with modern, social-based technologies enhanced student ability to effectively and efficiently build connections and integrate them into instructional practice and learner outcomes (Redish \& Williamson, 2009). The importance of the Internet addition not only increased productive communication within communities of practice but also presented students with "understanding of and ease with using technology that is part of the daily lives of professionals in other sectors," that is, to enhance the educational value to the students (U.S. Department of Education, Office of Educational Technology (USDOE, OOET), 2010, p. xii). With the Internet based social networks, the professor found student engagement in timely, self-interest topic searches and collaborations that would exist beyond the participants' immediate organization of their classroom setting. They would engage experts from around the world, colleagues across organizations, and mentor figures across barriers of physical location and time constraints. Access to primary sources once thought to be impossible can now be possible. The highlight of the course was accessing the FASB website, noted by students as "sobering" because the assignment allowed them to peruse not only letters of discussion, exposed drafts, notes and comments, but also engage in the standard setting process. This level of engagement allowed students to receive a comprehensive introduction to the process through internal and external levels of discussion first with oneself, others at the website, and later in a classroom community of their peers.

"Remember, new knowledge is like fresh fish. It has a very short shelf life." (Hall, 2005, p.38). The instructor chose to experiment and break free of the antiquated instructional methods and to develop activities that are interactive, complex, and inquiry-based within structure and content (Redish \& Williamson, 2009). By so doing, the instructor created an instructional design model that mirrored the expected outcomes while also truly accounting for student shortcomings. Hall (2005) described this concept as moment-in-time or just-in-time where instructors want and feel the need to apply the new skills being presented. The focus here is on providing an instructional program that models good instructional techniques and delivers skills that can be implemented immediately (Burns, 2002; Redish \& Williamson, 2009, Nudell, 2004). This moment-in-time application of techniques and skills was observed when students turned their attention to SEC's decision on the International Financial Accounting Standards (IFACS). Students were required to consider the issue of control in standard setting. The issue of control related to the dilemma on behalf of the good of the order for all or the protection of United States interests.

The study supported that Internet based social and professional networks within a capstone course enhances professional "pairings." The pairings are based on meaningful not superficial commonalities between members and, where interaction is frequent and sustained, it serves as breeding grounds for growth of knowledge (Wenger (2006). It is through these always-available social tools, learners can develop autonomous practices where self-directed problem solving and innovative thinking are spawned from consistent and sustained conversations that occur both synchronously and asynchronously. Furthermore, these features make it possible for the instructor to take a quick snapshot of the understanding of all the students in the class, immediately allowing the instructor to adjust instruction to match students' needs. A solution to traditional classroom lecture designs that treat students as inactive, interest inert, passive recipients of knowledge.

The instructor's in-class use of technology, computers and Internet access, works to everyone's advantage creating an active learning environment both inside and outside the classroom. Active learning, providing feedback, increasing attention span, and motivation are the four learning principles that have been identified as particularly challenging for Net Generation Learners (Nelson \& Hauck, 2008). Net Generation Learners are children who have grown up surrounded by digital media; hence, they are able to find obscure information in seconds. Senechal (2010) explains this is why educational reformers have demanded that classroom interaction be more immediate, useful, and relevant, with more attention to hands-on activities and less emphasis on traditional formal instruction and student output. The use of a "case course with a current issue paper "assigned for course credit is static and is interest inert, as compared to issues in-play (that is, emerging contemporary issues using interactive technology), where the issue is: 
- $\quad$ self-selected by the student because there is student self-interest in the topic,

- bandied about by classmates for discussion purposes,

- $\quad$ weighed in by students laced with facts and opinions,

- then leveraged with the application of the accounting standards FASB, professional auditing and consulting.

Net Generation Learners, who are also professors, integrate technology into classroom instruction and provide learners with computer driven techniques and sources that require students to not only search and identify issues, but also scrutinize said issues derived from articles and/or discussions enabling every student to actively respond to inquiries, while making information immediately available to help guide instruction (Beatty \& Gerace, 2009. p. 1). Thus, student use of the Internet to identify complex or ethical issues via searches of the American Institute of Certified Public Accountants (AICPA) website; the identification of emerging issues selected during inclass discussions measured against FASB website postings; and creating contentious issues via Trueblood Case Studies and an array of known audit failures such as Enron, WorldCom, Xerox, etc., willfully propels students into further scrutiny of these issues, and in fact, helps these Net Generation Learners gain access to knowledge that is readily available to support their learning. This optimum learning environment gives professor and students the tools they need to succeed and reach their full potential in the new global economy (Alexander \& HendersonRosser, 2010). Millennials, our nation's demographic age group of eighteen to thirty-three, are the Net Generation Learners most wirelessly connected with 82 percent using a laptop, cell phone, or similar device to access online resources and services (Pew Internet, 2010a). Thirty-three percent of our youth are the Smartphone users of the twenty-eight percent mobile subscribers in the United States (The Nielsen Company, 2010). In addition, 47\% of American adults report that they keep current by obtaining a portion of their local news through the use of a cell phone or tablet (Pew Internet, 2010b). So, one asks, why not avail students in this capstone course to be channeled by instructor's purpose and course intent to keep current and be in the moment, the issue in-play "real time" moment?

Just like professors, students need time to absorb new concepts, they need access to ongoing support and points of view to implement the instructional strategies, and they need to learn from instruction and in-class, face to face engagements, thereby, actualizing transference by not just viewing standards, but actually applying FASB on provocative topics and related accounting issues (Alexander \& Henderson-Rosser, 2010). The success of this model resides in the instructor's view that students are not passive learners, but active learners immersed in highly supported and sustained set of activities that have overt links to concrete or clearly identified issues in order to show purpose and need ((USDOE, OOET, 2010). We are no longer teaching to a solely verbal generation, but now a Net Generation of Learners (Tang \& Austin, 2009). These learners need active learning opportunities to keep them motivated to learn. Technology improves student interest, motivation, and engagement (Kay \& Knaack, 2009). This initiative considers the motivational factors that involve college students who voluntarily participate and do so with enthusiasm because of their self-selected topics or issues (Nagel, 2011). This model becomes a community effort because it enrolls all stakeholders in the learning process; it is activated by a process that is not solely driven from a top-down instructor but from soon to be accountants (Nagel, 2011). This ideal spawns the concept of "connected" teaching where individuals enlist the power of subject matter experts such as consultants, colleagues, and the instructor to work towards a common goal in this senior capstone course, the future of the accounting profession: be it auditing and tax preparation, or forensics and elder care consulting services, or specialized accounting firms (USDOE, OOET, 2010). Hart (2011) describes this ideal as work equaling learning and learning equaling work. There is always the opportunity to learn in all professional pursuits. In Hart's model, technology supports learning and does not limit or get in the way. It enables more communication, stronger connections between individuals, and spurs new and creative solutions. The end result of this process, and a focus of this instructor, is a more nimble and responsive employee that can quickly adapt to ever changing workplace situations.

The move by the instructor towards a focus on informal learning through "connected" environments fosters continual development and heightened agility in both individuals and in the larger organization, such as accounting (Jarche, 2011). The technology enriches learning by challenging students to gather information, synthesize, analyze, evaluate, and reply in verbal or written forms of communication, all of which are critical components of higher order thinking skills. This is key in this capstone accounting course since individuals rarely work in isolation using single point resources within organizations, but rather, in the creation of issue or subject matter networks resulting in 
collaboration within groups; groups that begin to epitomize the ideal of not only being able to fish, but they also begin to really learn how to learn how to fish (Jarche, 2011).

\section{CONCLUSION}

Incorporating contemporary issues in an accounting capstone course has now been successfully tried in an undergraduate and graduate course. We believe that the use of the Internet is the simplest and most direct method of achieving this goal. It is hoped that others will include a contemporary issues component in their accounting capstone courses (or capstone courses in other disciplines) accompanied by full integration of the learning tools of the Internet.

\section{AUTHOR INFORMATION}

Dr. Diane S. Bloom is Assistant Professor, School of Curriculum and Teaching and co-counsel for Kappa Delta Pi (KDP) International Education Honor Society, Kean University, Union, NJ. Research focuses on instruction, assessment, and teacher efficacy in diverse classroom settings. She previously served as assistant dean, director of student teaching and certification, Monmouth University; director of writing assessment for NJ State Department of Education; school administrator and teacher; and developed "New Jersey Registered Holistic Scoring Method for Writing Assessment". Degrees: Ed.D. from Rutgers - The State University of New Jersey, M.A. from Rowan University, and a B.S. from University of Minnesota. E-mail: dbloom@kean.edu

Dr. Clemense Ehoff Jr., CPA is Assistant Professor of Accounting, Kean University, Union New Jersey. He holds a Ph. D in Business Administration from San Francisco's Golden Gate University. He has more than 30 years professional business experience and has held full-time faculty and adjunct positions at universities predominantly in the Eastern United States. Over the last ten years, Dr. Ehoff has been involved in teaching accounting and tax courses in an online platform. He operates a consulting and tax practice. He has published articles in Elevator World, and other journals. E-mail: drehoff@ comcast.net, corresponding author

\section{REFERENCES}

1. Alexander, S. \& Henderson-Rosser, A. (2010). Do-it-yourself professional development. Learning with Technology, 37(8), 24-27.

2. $\quad$ Beatty, I.D. \& Gerace, W.J. (2009). Technology-enhanced formative assessment: A research-based pedagogy for teaching science with response to technology. Journal of Science Education Technology, 18, 146-162. doi: 10.1007/s10956-008-9140-4.

3. Burns, M. (2002). From black and white to color: Technology professional development and changing practice. T.H.E. Journal, 29(11), 36-42. Retrieved February 15, 2007 from Wilsonweb database.

4. $\quad$ Deloitte Development, LLC. (2009). Retrieved January 5, 2010 from http://www.deloitte.com/view/en_US/us/Services/audit-enterprise-risk-services/Financial-StatementInternal-Control-Audit/Accounting-StandardsCommunications/article/7692899a961fb110VgnVCM100000ba42f00aRCRD.htm.

5. Ehoff, C. (2010, March) Notes on Accounting Capstone Course Design: Contemporary Issues Versus Case Analysis Enhances Student Interest and Learning. Contemporary Issues In Education Research, Vol. 3, No. 3, 59-62.

6. Financial Accounting Standards Board (FASB) Discussion Paper: Preliminary Views on Financial Statement Presentation. Retrieved November 25, 2009 from http://www.fasb.org/DP_Financial_Statement_Presentation.pdf

7. Hall, D. (2005). Moving from professional development to professional growth. Learning \& Leading with Technology, 32(5), 36-38. Retrieved January 19, 2007 from Wilsonweb database.

8. Hart, J. (2011). Social Learning Handbook. LaVergne, TN: Centre for Learning \& Performance Technologies.

9. Jarche, H. (2011). White Paper: A framework for the social enterprise. Retrieved April 27, 2011 from http://www.jarche.com/wp-content/uploads/2010/09/Social-Enterprise-White-Paper.pdf. 
10. Kay, R., \& Knaack, L. (2009). Exploring the use of audience response systems in secondary school science classrooms. Journal of Science Education \& Technology, 18, 382-392.

11. Nagel, D. (2011). Bringing teachers onboard with tech. The Journal. Retrieved April 9, 2011 from http://thejournal.com/articles/2011/01/27/bringing-teachers-onboard-with-tech.aspx?sc_lang=en.

12. Nelson, M.L. \& Hauck, R.V. (2008). Clicking to learn: A case study of embedding radio frequency based clickers in an introductory management information systems course. Journal of Information Systems Education, 19(1), 55-64.

13. Nudell, H. (2004-2005). Time to experiment: The role of exploration in professional development. Learning \& Leading with Technology, 32(4), 50-53. Retrieved January 19, 2007 from Wilsonweb database.

14. Pew Internet and American Life Project. (2010a). Generations 2010. Retrieved April 3, 2010 from http://pewinternet.org/Reports/2010/Generations-2010.aspx.

15. Pew Internet and American Life Project. (2010b). How mobile devices are changing community information environments. Retrieved April 17, 2011 from http://pewinternet.org/Reports/2010/Generations2011/Local---mobile---news.aspx.

16. Pratibha K. Value Notes: Offshoring Tax Retruns Preparation to India. Retrieved from http://www.sourcingnotes.com/content/view/197/54/

17. Redish, T., \& Williamson, J. (2009). ISTE's Technology Facilitation and Leadership Standards. International Society for Technology in Education. Retrieved April 26, 2011 from http://www.iste.org/images/excerpts/TLPREP-excerpt.pdf.

18. Senechal, D. (2010). The most daring education reform of all. American Educator, 34(1), 4-16.

19. Tang, T., \& Austin, M. J. (2009). Students' perceptions of teaching technologies, application of technologies, and academic performance. Computers \& Education, 53(4), 1241-1255. doi:10.1016/j.compedu.2009.06.007.

20. The Nielson Company (2010). Mobile youth around the world. Retrieved April 4, 2011 from http://www.nielsen.com/us/en/insights/reports-downloads/2010/mobile-youth-around-the-world.html.

21. U. S. Department of Education. (2010). Transforming American Education: Learning powered by technology. Washington, DC: Office of Educational Technology. Retrieved from http://www.ed.gov/technology/netp-2010.

22. Weirich, T. R., Pearson, T. C., \& Churyk, N. T. (2010). Accounting \& Auditing Research: Tools \& Strategy. Hoboken, NJ, Wiley.

23. Weiss, M. D. (July 5, 2002). The Worsening Crisis of Confidence on Wall Street. Retrieved April 13, 2009 from http://www.weissratings.com/worsening_crisis.asp. 